\title{
Fen Bilgisi Öğretmen Adaylarının Epistemolojik İnançlarının Araştırma Sorgulamaya Dayalı Fen Öğretimi ve Bilimsel Tutum Üzerine Etkilerinin Çoklu Regresyon ile Analizi*
}

\author{
Analysis of the Effects of Pre-service Science Teachers' \\ Epistemological Beliefs on Teaching Science as Scientific \\ Inquiry and Scientific Attitude through Multiple Regression*
}

\author{
Murat AVCI**, Ayşe YENILIMEZ TÜRKOĞLU***, Hüseyin EŞ****
}

\begin{abstract}
Öz: Bu araştırmada fen bilgisi öğretmen adaylarının epistemolojik inançlarıyla araştırma-sorgulamaya dayalı fen öğretimi inançları ve bilimsel tutumları arasındaki ilişkilerin incelenmesi amaçlanmıştır. Araştırmanın örneklemini 6 farklı devlet üniversitesinde fen bilgisi öğretmenliği programında öğrenim gören 329 öğretmen adayı oluşturmuştur. Araştırma nicel araştırma yöntemlerinden tarama modelindedir. Veriler, Epistemolojik İnanç Ölçeği, Araştırma Tabanlı Fen Öğretimi Ölçeği ve Bilimsel Tutum Ölçeği kullanılarak toplanmıştır ve betimsel ve çıkarımsal istatistiksel analizler yoluyla incelenmiştir. Araştırmanın her bir değişkeni için, minimum, maksimum, ortalama ve standart sapma değerlerini içeren betimsel analizler gerçekleştirilmiş; ortalama değerlerin cinsiyete göre değişip değişmediği 'bağımsız örneklemler için t-testi', değişkenler arası ilişki olup olmadığı 'Pearson moment çarpım korelasyonu' ve öğrenmenin çabaya bağlı olduğuna dair inancın, öğrenmenin yeteneğe bağlı olduğuna dair inancın ve tek bir doğrunun olduğuna dair inancın, araştırma-sorgulamaya dayalı fen öğretimi inancını ve bilimsel tutumu yordama gücü ise çoklu regresyon analizleri ile incelenmiş̧tir. Bulgular, fen bilgisi öğretmen adaylarının öğrenmenin çabaya bağlı olduğuna inandıklarını ve öğrenmenin çabaya bağlı olduğuna dair inancın araştırma-sorgulamaya dayalı fen öğretimi inancındaki değişimin yaklaşı \%33'ünü, bilimsel tutumdaki değişimin ise \%14'ünü açıkladığını göstermiştir.
\end{abstract}

Anahtar Kelimeler: Fen bilgisi öğretmen adayları, epistemolojik inanç, araştırma-sorgulamaya dayalı fen öğretimi, bilimsel tutum

\begin{abstract}
The aim of this study was to investigate the relationships among pre-service science teachers' epistemological beliefs, science teaching beliefs and scientific attitudes. The study was designed as a survey research and the sample consisted of 329 pre-service science teachers from 6 different state universities. Data were collected using Epistemological Beliefs Questionnaire, Teaching Science as Inquiry Instrument and Scientific Attitude Scale, and were analyzed through descriptive and inferential statistical analyses. For each variable of the study, descriptive analyzes including minimum, maximum, mean and standard deviation values were calculated; and independent samples t-test for the possible mean differences with respect to gender, Pearson moment-product correlation for the relationships among the variables, and multiple regression analyses for the predictive power of epistemological beliefs on teaching science as inquiry and scientific attitude were conducted. According to the findings of the study, pre-service science teachers believed that learning depends on effort. Multiple regression analyses showed that the belief that learning depends on effort explained 33\% of the variance in inquiry-based science teaching self-efficacy, while it explained $14 \%$ of the variance in scientific attitude.
\end{abstract}

Keywords: Pre-service science teachers, epistemological belief, teaching science as inquiry, scientific attitude

\footnotetext{
* Bu makale, birinci yazarın 'Fen Bilgisi Öğretmen Adaylarının Epistemolojik İnançlarıyla Sorgulamaya Dayalı Fen Öğretimi İnançları, Bilimsel Tutumları ve Akademik Başarıları Arasındaki İlişkinin İncelenmesi’ isimli yüksek lisans tezinden üretilmiştir.

** Öğretmen, İstanbul-Türkiye, ORCID: 0000-0002-2671-0962, e-posta: avcimurat34@ gmail.com

*** Dr. Öğrt. Üyesi, Alanya Alaaddin Keykubat Üniversitesi, Eğitim Fakültesi, Alanya/Antalya-Türkiye, ORCID: 0000-0002-1981-2813, e-posta: ayse.yenilmez@alanya.edu.tr

**** Dr. Öğrt. Üyesi, Sinop Üniversitesi, Eğitim Fakültesi, Sinop-Türkiye, ORCID: 0000-0001-8294-5080, e-posta: huseyines@sinop.edu.tr
} 
Fen Bilgisi Öğretmen Adaylarının Epistemolojik İnançlarının Araştırma Sorgulamaya Dayalı Fen

Öğretimi ve Bilimsel Tutum Üzerine Etkilerinin Çoklu Regresyon ile Analizi

\section{Giriş}

İnsanlar yaşantıları boyunca bilinçli olsun ya da olmasın dış dünya ile etkileşim halinde bulunmaktadırlar. Bu etkileşimler sonucunda çevre ile ilgili birtakım yargı, değer ve tutum benzeri kazanımlara ulaşmakta ve bu değerler ve tutumlar davranışları etkilemektedirler. İnanç kavramı, bir şeyin önemi düşünülürken bir gerçeklik; ilke ya da kanun hakkında fikirler ortaya çıkaran ve aklın ötesinde bilgiler içeren düşüncelerdir (Dewey, 1933). İnançlar davranışı doğuran ve belirleyen eğilimlerdir. Dolayısıyla bilgi ile inanç birbirleri ile yakın olsalar da, bilgi doğruluğu ve geçerliği kanıtlanabilen, gözlem ile ortaya çıkan nesnel olguları içerirken, inanç ise belirli bir bireyin doğru olarak kabul ettiği duygular, değerlendirmeler ve yargılamalardır (Deryakulu, 2006). Yani, inançlar bilgilerle beslenen ama bilgilere de bağımlı olmayan davranışlardır. Bilgiler daha çok sistemli olmakla birlikte tutarlı ve mantıklı bir şekildeki bilişsel yapıları şekillendirirken, inanç ise sadece bilişsel yapıları değil duyuşsal yapıları da şekillendirmektedir (Pajares, 1992). Epistemolojik inançlar ise bilginin doğası, sınırları, doğruluğu, güvenirliği ve geçerliğini araştırmayı konu edinen bir disiplin olarak tanımlanmaktadır (Demir ve Acar, 1992). Bir başka tanımla epistemolojik inanç, kişinin zihninde oluşturduğu bilginin niteliği, bilgiye ulaşma yollarıyla ilgili yaklaşımlar, düşünceleri ve sahip olduğu bilgi yapılarını ifade etmektedir (Deryakulu, 2006).

Epistemolojik inancı tanımlamaya çalışan araştırmacılar epistemolojik inancın farklı yönlerine vurgu yapmaktadırlar. Bireylerin düşünce ve davranışlarında en güçlü etkinin inanç olması, eğitimcilerin eğitim ve öğretim süreçlerinde epistemolojik inançların etkisini dikkate almalarını sağlamıştır (Deryakulu, 2006). Epistemolojik inançlar en net biçimde, bireylerin bilginin ne olduğu ve bilme ve öğrenmenin nasıl gerçekleştiği ile ilgili öznel inançları tanımlamaktadır (Deryakulu, 2006; Schommer, 1990). Bireylerin epistemolojik inançları; gelişmiş (sophisticated) ve gelişmemiş (naive) olarak açıklanabilir (Brownlee ve diğerleri, 2001). Gelişmemiş (naive) inanç, bilginin kesin ve mutlak olduğu, dolayısıyla da bir uzmandan aktarılabileceği yönündeki inançtır. Gelişmemiş inanca sahip bireylerin; bilginin tek parçadan oluşan basit bir yapıya sahip olduğu, bilginin mutlak olarak doğru ya da yanlıştan meydana geldiği, öğrenme yeteneğinin doğuştan yani genetik olarak gelen değişmez bir yetenek olduğu, bireylerin bilgiyi ya anında öğrendiği ya da hiç öğrenemediği ve bilginin sadece uzmanlar tarafından oluşturulduğu inancında oldukları belirtilmiştir (Deryakulu, 2002). Gelişmiş (sophisticated) inanç ise bireyin bilgiyi göreceli, değişken ve yeniden yapılandırılabilir olarak kabul ettiğine yönelik inançlardır (Brownlee ve diğerleri, 2001). Gelişmiş inançlara sahip bireyler; bilginin birbirleriyle bağlantılı birçok parçadan meydana gelmiş karmaşı bir yapıya sahip olduğu, öğrenme yeteneğinin gelişebileceği, bilgilerin deneysel kanttlara dayanarak ya da bireylerin aklı yoluyla oluşturulabileceği ve öğrenmenin çabaya bağlı olarak zaman içinde gerçekleşebileceğine yönelik inançlara sahiptirler. Epistemolojik inançların yanında, bireyin bilim ile ilgili hayatını etkileyen en önemli olgulardan biri de bilimsel tutumdur.

Demirbaş ve Yağbasan (2006) bilimsel tutumu, anlamaya ve bilmeye karşı isteklilik, veri toplama ve araştırma, doğruluğun ne olduğunun kanıtlanması ve arzusu ve mantığa sayg1 duyulması gibi sonuçların düşünülmesi şeklinde ifade etmektedirler. Başaran (1978) ise bilimsel tutumu bireyin karşılaştıkları tüm sorunları ve olayları kendi duyguları ve hislerinden ayırıp elinde bulunan mantıksal verilerle birlikte yorumlaması şeklinde tanımlamıştır. Bilimsel tutumlara sahip bireyler, araştırmacı, eleştirici özelliklere sahip olup, peşin yargılardan ve dogmatik inanç sisteminin etkisinden uzak olmaktadırlar. Bilimsel tutumlar bireylerin sadece başarılı olması ile ilgili olmayıp kişisel gelişiminin sürekli kılınması ile de ilgilidir (Başaran, 1978). Liaghatdar, Jafari, Abedi ve Samiee'ye (2008) göre, olumlu bilimsel tutumlara sahip olan ögrencilerin başarıları ve hayata karşı performansları ilerlemekteyken, bilime ve bilimle alakalı konulara ilgileri de artmaktadır. Bilimsel tutum ve davranışlar bireylerde bilimsel düşünme ve yaşamanın temellerini barındırmaktadır. Bilime karşı olumlu tutuma sahip olan öğrenciler eğitim programlarına, derslerine, öğretmenlerine ve okullarına karşı da olumlu tutum geliştirmektedirler (Mihladız ve Duran, 2011). Bu bağlamda, öğrencilerde olumlu bilimsel tutumun geliştirilmesinde araştırma-sorgulamaya dayalı fen öğretimi ön plana çıkmaktadır. Araştırma-sorgulama; gözlemleme, bilinen bilgiler için kaynak taraması, konu hakkındaki araştırmayı planlama, 
bildikleri bilgileri deneysel kanttlarla birlikte yeniden gözden geçirme, verileri analiz etme, yorumlama ve elde ettikleri sonuçları aktarma gibi bilim insanlarınınkine benzer öğrenci aktiviteleridir (NRC, 1996). Araştırma-sorgulamaya dayalı öğretimde dört bilimsel yeterlilik ise 'bilimsel söylemlere verimli katılmak', 'bilimsel bilginin doğasını anlamak', 'bilgileri bilimsel kanıt oluşturarak değerlendirmek' ve 'bilimsel açıklamalarını bilmek ve bunları yorumlamak' şeklinde ifade edilmektedir (Duschl, Schweingruber ve Shouse, 2007).

Son yıllarda ülkemiz fen bilimleri öğretim programlarında önemli değişimler gerçekleşmektedir. $\mathrm{Bu}$ değişimlerle birlikte fen bilimleri öğretim programında temel alınan yapılandırmacı öğrenme yaklaşımının yanında araştırma-sorgulamaya dayalı öğrenme de önem kazanmıştır (Avcı, 2019). Program, bireylerden bilgiyi araştırmalarını, sorgulamalarını ve bu bilgilerin zamanla değiştiğini kavramalarını beklemektedir (MEB, 2018). Programı öğrenciler ile buluşturacak olan eğitim sisteminin belki de en önemli öğesi ise öğretmendir. Sıklıkla söylendiği gibi, iyi öğretmenler en kötü programı kurtarabilir, kötü öğretmenler en iyi programı batırabilir (Matthews, 2017). Program kazanımlarının öğrenciler tarafından edinilmesini sağlamanın yanında öğretmenler ayrıca birer rol-modeldirler. Dolayısıyla bu bilgi ve becerileri öğrencilere kazandıracak olan öğretmen adaylarının sorgulamaya dayalı fen öğretim inançları, epistemolojik inançları ve bilimsel tutumlarının ne düzeyde olduğunun ve birbirleri ile ilişkilerinin araştırılması bir gereklilik olarak karşımıza çıkmaktadır. Bu noktada, bu araştırmanın problem cümlesi, 'Fen bilgisi öğretmen adaylarının epistemolojik inançlarıyla araştırma-sorgulamaya dayalı fen ögretimi öz yeterlilik inançları ve bilimsel tutumları arasında ilişki var mıdır?' olarak belirlenmiş̧tir. Alt problemleri ise; araştırmaya katılan fen bilgisi öğretmen adaylarının,

1. Epistemolojik inançları ne düzeydedir?

2. Araştırma-sorgulamaya dayalı fen öğretimi öz yeterlilik inançları ne düzeydedir?

3. Bilimsel tutumları ne düzeydedir?

4. Araştırmanın değişkenleri (epistemolojik inanç, araştırma-sorgulamaya dayalı fen öğretimi ve bilimsel tutum) açısından kadın ve erkek öğretmen adayları arasında fark var mıdır?

5. Epistemolojik inançların alt faktörleri olan öğrenmenin çabaya bağlı olduğuna dair inanç, öğrenmenin yeteneğe bağlı olduğuna dair inanç ve tek bir doğrunun olduğuna dair inanç, araştırma-sorgulamaya dayalı fen öğretimi öz yeterlilik inancını yordamakta mıdır?

6. Epistemolojik inançların alt faktörleri olan öğrenmenin çabaya bağlı olduğuna dair inanç, öğrenmenin yeteneğe bağlı olduğuna dair inanç ve tek bir doğrunun olduğuna dair inanç, bilimsel tutumu yordamakta mıdır? şeklindedir.

\section{Yöntem}

Nicel araştırma yöntemi benimsenerek yapılan bu araştırma, tarama (survey) modelindedir. Bu araştırmalarda genellikle popülasyonun belirli bir konu veya sorun hakkındaki görüşleriyle ilgilenilir ve popülasyonun ilgilenilen yönlerini veya özelliklerini tanımlamak için onu oluşturan her bireyden değil, bir örneklem grubundan veri toplanır (Fraenkel ve Wallen, 1996).

\section{Örneklem}

Araştırmada seçkisiz olmayan örnekleme yöntemlerinden uygun örnekleme yönteminden yararlanılmıştır (Fraenkel ve Wallen, 1996). Araştırmanın örneklem grubunu üçüncü ve dördüncü sinıflarda öğrenim gören toplam 329 (248 kadın, 81 erkek) fen bilgisi öğretmen adayı oluşturmuştur. Bu sınıf seviyelerindeki öğretmen adaylarının tercih edilme nedeni ise, fen bilgisi ögretmenliği programında bilimin doğası ve bilim tarihi dersinin bu düzeydeki öğrencilerce tamamlanmış olmasıdır.

\section{Veri toplama araçları}

Araştırmada veri toplama aracı olarak, Schommer (1990) tarafından geliştirilen ve Deryakulu ve Büyüköztürk (2005) tarafından Türkçeye uyarlanan 'Epistemolojik İnanç Ölçeği', Moore ve Foy (1997) tarafından geliştirilen ve Demirbaş ve Yağbasan (2006) tarafından Türkçeye uyarlanan 'Bilimsel Tutum Ölçeği' ve Smolleck, Zembal-Saul ve Yoder (2006) tarafindan geliştirilen ve İnaltekin ve Akçay (2011) tarafindan Türkçeye uyarlanan 'Araştırma Tabanlı Fen Öğretimi Ölçeği' kullanılmıştır. 
Epistemolojik İnanç Ölçeği: 'Epistemolojik İnanç Ölçeği' Schommer tarafından 1990 yılında geliştirilmiş ve Deryakulu ve Büyüköztürk (2005) tarafından Türkçe'ye uyarlanmıştır. Schommer tarafından geliştirilen ölçek, kesinlikle katılmıyorum, katılmıyorum, kararsızım, katılıyorum ve tamamen katıllyorum şeklinde 5'li Likert tipinde 63 maddeden oluşurken, Deryakulu ve Büyüköztürk gerçekleştirdikleri analizler sonucunda kültürel farklılıklardan kaynaklı değişiklikleri de yansıtarak, 'öğrenmenin çabaya bağlı olduğuna inanç', 'öğrenmenin yeteneğe bağlı olduğuna inanç' ve 'tek bir doğrunun olduğuna inanç' şeklinde üç faktör içeren ve 35 maddeden oluşan, ölçeğin Türkçe halini geliştirmişlerdir. Ölçekten alınan puan ortalaması düştükçe sofistike, yani epistemolojik inançları gelişmiş, ortalama yükseldikçe ise 'naive', yani epistemolojik inançları gelişmemiş inançlara sahip olunduğu sonucuna ulaşılmaktadır (Deryakulu 2002; 2006). Schommer'e (1990) göre tam ortada yer alan bireyler (2,50 ile 3,50 ortalama) ise, güçlü bir inanç sergilememektedirler (Karhan, 2007). Güvenilirlik analizi kapsamında, bu çalışmada, ölçeğin geneli için hesaplanan Cronbach's Alpha değeri 0,843 olarak bulunurken, bu değer 'öğrenmenin çabaya bağl1 olduğu inanç' boyutu için 0,81 , 'öğrenmenin yeteneğe bağl1 olduğu inanç' boyutu için 0,864 ve 'tek bir doğrunun varlığına inanç' boyutu için 0,731 olarak bulunmuştur.

Araştırma Tabanlı Fen Öğretimi Ölçeği: Smolleck, Zembal-Saul ve Yoder (2006) tarafindan geliştirilen ve İnaltekin ve Akçay (2011) tarafından Türkçe'ye uyarlanan 'Araştırma Tabanlı Fen Öğretimi Ölçeği' (ATFÖ), kesinlikle katılmıyorum, katılmıyorum, kararsızım, katılıyorum ve tamamen katılıyorum şeklinde 5'li Likert tipinde 69 maddeden oluşmaktadır. Ölçeğin, 'firsat', 'rehberlik', 'kanıt' ve 'açıklama' şeklinde dört alt boyutu bulunmaktadır. Ölçekten alınan puan ortalaması düştükçe araştırma tabanlı fen öğretimi öz yeterlilik inancı azalırken, ortalama yükseldikçe öz yeterlilik inancı artmaktadır. Bu çalışmada, ölçeğin tamamına ait Cronbah's Alpha değeri 0,947 olarak bulunmuştur. Alt boyutlar incelendiğinde ise, 'firsat' boyutu için 0,876 , 'rehberlik' boyutu için 0,873 , 'kanıt' boyutu için 0,880 ve 'açıklama' boyutu için ise 0,947 değerlerine ulaşılmıştır.

Bilimsel Tutum Ölçeği: Moore ve Foy (1997) tarafından geliştirilen ve Demirbaş ve Yağbasan (2006) tarafindan Türkçe'ye uyarlanan 'Bilimsel Tutum Ölçeği' (BTÖ), kesinlikle katılmıyorum, katılmıyorum, kararsızım, katılıyorum ve tamamen katıliyorum şeklinde 5'li Likert tipinde toplam 40 maddeden oluşmaktadır. Ölçekte yer alan maddeler, öğrencilerin fen bilimlerinin doğası, bilim insanlarının çalışma biçimi ve fen bilimleri hakkında neler hissettiğini açıklamak amacıyla yapılandırılmıştır. 40 soruluk ölçekteki soruların 20 tanesi pozitif cümlelerden, kalan 20 tanesi de negatif cümlelerden oluşmaktadır. Ölçek için bu çalışmada hesaplanan Cronbach's Alpha değeri 0,694 olarak bulunmuştur.

\section{Verilerin analizi}

Verilerin analizinde PASW-23.0 paket programı kullanılmıştır. Fen bilgisi öğretmen adaylarından araştırmanın amaçları doğrultusunda toplanan veriler, alt problemleri içerecek şekilde betimsel ve çıkarımsal istatistiksel analizler yoluyla incelenmiştir. Araştırmanın her bir değişkeni için, minimum, maksimum, ortalama ve standart sapma değerlerini içeren betimsel analizler gerçekleştirilmiştir. Diğer yandan, değiş̧kenler arası ilişki olup olmadığ 1 'Pearson moment çarpım korelasyonu' ile test edilmiş̧ir. Son olarak, araştırmaya katılan fen bilgisi öğretmen adaylarının, öğrenmenin çabaya bağlı olduğuna dair inançlarının, öğrenmenin yeteneğe bağlı olduğuna dair inançlarının ve tek bir doğrunun olduğuna dair inançlarının, araştırmasorgulamaya dayalı fen öğretimi öz yeterlilik inançlarını ve bilimsel tutumlarını yordama durumunu hesaplamak amacıyla ise 'çoklu regresyon analizleri' yapılmıştır. $\mathrm{Bu}$ araştırmada gerçekleştirilen çoklu regresyon analizlerinin yordayıcı (bağımsız) değişkenleri öğrenmenin çabaya bağlı olduğuna dair inanç, öğrenmenin yeteneğe bağlı olduğuna dair inanç ve tek bir doğrunun olduğuna dair inanç iken, yordanan (bağımsız) değişkenler ise, araştırma-sorgulamaya dayalı fen ögretimi öz yeterlilik inancı ile bilimsel tutum olmuştur. Analizlerde anlamlılık düzeyi 0,05 olarak belirlenmiştir. 


\section{Bulgular}

Fen bilgisi öğretmen adaylarının epistemolojik inançlarına ilişkin bulgular

Araştırmaya katılan fen bilgisi öğretmen adaylarının epistemolojik inançlarını belirlemek amacıyla 'Epistemolojik İnanç Ölçeği' kullanılmıştır. Ölçek 3 alt boyuttan oluşmaktadır ve ölçekten alınan toplam puanların ortalamasından ziyade değerlendirme faktör bazında yapılmaktadır (Deryakulu ve Büyüköztürk, 2005). 5'li Likert tipindeki ölçekten elde edilen faktör puan ortalamaları incelendiğinde, fen bilgisi öğretmen adaylarının öğrenmenin çabaya bağlı olduğuna dair inançlarının ortalama puanlarının oldukça düşük olduğu $(M=1,93)$ görülmektedir. Fen bilgisi öğretmen adaylarının öğrenmenin yeteneğe bağlı olduğuna dair inançlarının ortalama puanlarının $(M=2,68)$ ve tek bir doğrunun var olduğuna dair inanç ortalama puanlarının $(M=3,17)$ orta değere yakın olduğu görülmektedir (Tablo 1).

Tablo 1.

Katılımcıların Epistemolojik İnançlarına İlişkin Betimsel İstatistiksel Bulgular

\begin{tabular}{llllll}
\hline Değgişken & $\mathrm{N}$ & Min. & Max. & Ort. & $\mathrm{S}$ \\
\hline Öğrenmenin çabaya bağl1 olduğuna inanç & 329 & 1,0 & 3,83 & 1,93 & 0,469 \\
Öğrenmenin yeteneğe bağlı olduğuna inanç & 329 & 1,0 & 5,0 & 2,68 & 0,907 \\
Tek bir doğrunun var olduğuna inanç & 329 & 1,56 & 5,0 & 3,17 & 0,671 \\
\hline
\end{tabular}

Ölçekten alınan puan ortalaması düştükçe sofistike, yani epistemolojik inançları gelişmiş, ortalama yükseldikçe ise 'naive', yani epistemolojik inançları gelişmemiş inançlara sahip olunduğu sonucuna ulaşıldığından (Deryakulu, 2002; 2006), araştırmaya katılan fen bilgisi öğretmen adaylarının, öğrenmenin gerçekleşebilmesi için çaba sarf etmeye gerek olduğuna inandıkları düşünülebilir. Schommer'e (1990) göre tam ortada yer alan bireyler (2,50 ile 3,50 ortalama) ise, güçlü bir inanç sergilememektedirler (Karhan, 2007). Bu durumda, bu araştırmaya katılan öğretmen adaylarının, öğrenmenin yeteneğe bağlı olduğu ve tek bir doğrunun var olduğu konusunda güçlü bir inanç sergilemedikleri söylenebilir.

Fen bilgisi öğretmen adaylarının araştırma-sorgulamaya dayalı fen öğretimi öz yeterlilik inanç düzeylerine ilişkin bulgular

Araştırmaya katılan fen bilgisi öğretmen adaylarının, araştıran ve sorgulayan bireyler yetiştirmede önemli bir belirleyici olduğu düşünülen araştırma-sorgulama becerilerine yönelik inanç düzeylerini incelemek amacıyla 'Araştırma Tabanlı Fen Öğretimi Öz Yeterlilik Ölçeği' kullanılmıştır. Ölçek 5'li Likert tipinde toplam 4 alt boyuttan oluşmaktadır. Tablo 2'de görüldüğü gibi, öğretmen adaylarının araştırma-sorgulamaya dayalı fen öğretimine ilişkin inanç düzeylerinin, ölçeğin tamamı ve alt boyutları için, yüksek düzeyde olduğu görülmektedir.

Tablo 2.

Katılımcıların Araştırma-Sorgulamaya Dayalı Fen Öğretimine İlişkin Betimsel İstatistiksel Bulgular

\begin{tabular}{llllll}
\hline Değišken & $\mathrm{N}$ & Min. & Max. & Ort. & $\mathrm{S}$ \\
\hline ATFÖ Toplam & 329 & 1,97 & 5,0 & 4,14 & 0,414 \\
Firsat & 329 & 1,94 & 5,00 & 4,18 & 0,446 \\
Rehberlik & 329 & 1,76 & 5,47 & 4,18 & 0,459 \\
Kanıt & 328 & 2,00 & 5,00 & 4,19 & 0,444 \\
Açıklama & 329 & 2,14 & 5,00 & 3,96 & 0,478 \\
\hline
\end{tabular}

Tablo 2'de sunulan bulgular, fen bilgisi öğretmen adaylarının araştırma-sorgulamaya dayalı fen öğretimini organize etmede yapabileceklerine ilişkin olumlu düzeyde fen öğretimi öz yeterlilik inancına sahip olduklarını göstermektedir. Bir başka deyişle, öğretmen adayları kendilerini, öğrencileri bilimsel sorularla meşgul edecek; onları, soruları cevaplamadan önce 
kanıtlar sunacak ve kanıtları kullanarak açıklamalar yapacak ve açıklamalarını diğerleriyle paylaşıp savunacak öğretim etkinliklerine yönlendirebilecekleri konusunda yeterli hissetmektedirler.

\section{Fen bilgisi öğretmen adaylarının bilimsel tutumlarına ilişkin bulgular}

Bilimsel tutuma sahip bireylerin, araştıran, eleştiren ve peşin yargıların ve dogmatik inanç sistemlerinin etkisinde kalmayan bireyler oldukları belirtilmektedir (Demirbaş ve Yağbasan, 2006). Bu araştırmaya katılan fen bilgisi öğretmen adaylarının bilimsel tutumlarını belirlemek amacıyla, 5'li Likert tipinde toplam 6 alt boyuttan oluşan 'Bilimsel Tutum Ölçeği' kullanılmıştır. Bulgular, öğretmen adaylarının bilimsel tutum düzeylerinin, ölçeğin geneli ve alt boyutlarında, kararsıza yakın düzeyde olduğunu göstermiştir (Tablo 3).

Tablo 3.

Katılımcıların Bilimsel Tutumlarına İlişkin Betimsel İstatistiksel Bulgular

\begin{tabular}{llllll}
\hline Değişken & N & Min. & Max. & Ort. & S \\
\hline BTÖ Toplam & 329 & 2,15 & 5,00 & 3,43 & 0,323 \\
\hline Bilimsel kanunlar ve teorilerin yapısıı & 329 & 2,00 & 5,00 & 3,42 & 0,415 \\
$\begin{array}{l}\text { Fen bilimlerinin yapısı ve olaylara yaklaşma } \\
\text { biçimi }\end{array}$ & 329 & 2,17 & 5,00 & 3,42 & 0,554 \\
Bilimsel davranışı sergileme & & & & & \\
Fen bilimlerinin yapısı ve amacı & 329 & 2,00 & 5,00 & 3,50 & 0,681 \\
Fen bilimlerinin toplumdaki yeri ve önemi & 329 & 2,00 & 5,00 & 3,53 & 0,605 \\
Bilimsel çalışmaları yapmadaki isteklilik & 329 & 1,67 & 5,00 & 3,15 & 0,613 \\
& 329 & 1,20 & 5,00 & 3,53 & 0,448 \\
\hline
\end{tabular}

Tablo 3'te verilen bulgular, araştırmaya katılan fen bilgisi öğretmen adaylarının, bilimsel olayların yapısı, doğası, amacı, bilimsel düşünme, bilimsel davranış, bilimsel yöntem gibi konularda olumlu düzey yönünde ama kararsız yapıda olduklarını göstermiştir.

\section{Araştırmanın değişkenleri açısından kadın ve erkek öğretmen adayları arasındaki farklara} ilişkin bulgular

Araştırmaya katılan fen bilgisi öğretmen adaylarının cinsiyetlerine göre araştırmanın değişkenleri açısından aldıkları ortalama puanlar ve standart sapma değerleri Tablo 4 'te verilmiştir.

Tablo 4.

Araştırmanın Değişkenlerine Göre Kadın ve Erkek Adaylara Ait Betimsel İstatistiksel Bulgular

\begin{tabular}{lllll}
\hline Değişken & Cinsiyet & $\mathrm{N}$ & Ort. & $\mathrm{S}$ \\
\hline Öğrenmenin çabaya bağlı olduğuna inanç & Kadın & 248 & 1,91 & 0,473 \\
& Erkek & 81 & 1,98 & 0,455 \\
\multirow{2}{*}{ Öğrenmenin yeteneğe bağlı olduğuna inanç } & Kadın & 248 & 2,59 & 0,894 \\
& Erkek & 81 & 2,96 & 0,897 \\
\multirow{2}{*}{ Tek bir doğrunun var olduğuna inanç } & Kadın & 248 & 3,13 & 0,655 \\
\multirow{2}{*}{ Araştırma-sorgulamaya dayalı fen öğretimi öz } & Erkek & 81 & 3,26 & 0,712 \\
yeterlilik inanc1 & Kadın & 248 & 4,15 & 0,409 \\
Bilimsel tutum & Erkek & 81 & 4,06 & 0,408 \\
& Kadın & 248 & 3,45 & 12,27 \\
& Erkek & 81 & 3,40 & 14,75 \\
\hline
\end{tabular}

Tablo 4 incelendiğinde, araştırmanın değişkenleri açısından kadın ve erkek öğretmen adaylarının ortalama puanları arasında farklar görülmektedir. Bu farkların istatistiksel olarak anlamlı olup olmadığını araştırmak amacıyla, her bir değişken için bağımsız örneklemler için ttesti analizi yapılmıştır. 
Tablo 5.

Araştırmanın Değişkenlerine Göre Cinsiyet İçin t-Testi Analizi Bulguları

\begin{tabular}{|c|c|c|c|c|c|c|c|}
\hline Değişken & Cinsiyet & $\mathrm{N}$ & Ort. & SS & $\mathrm{SD}$ & $\mathrm{t}$ & $\mathrm{p}$ \\
\hline \multirow{2}{*}{$\begin{array}{l}\text { Öğrenmenin çabaya bağl1 } \\
\text { olduğuna inanç }\end{array}$} & Kadın & 248 & 1,91 & 0,473 & \multirow{2}{*}{327} & \multirow{2}{*}{$-1,103$} & \multirow{2}{*}{,271 } \\
\hline & Erkek & 81 & 1,98 & 0,455 & & & \\
\hline \multirow{2}{*}{$\begin{array}{l}\text { Öğrenmenin yeteneğe bağlı } \\
\text { olduğuna inanç }\end{array}$} & Kadın & 248 & 2,59 & 0,894 & \multirow{2}{*}{327} & \multirow{2}{*}{$-3,196$} & \multirow{2}{*}{, 002} \\
\hline & Erkek & 81 & 2,96 & 0,897 & & & \\
\hline \multirow{2}{*}{$\begin{array}{l}\text { Tek bir doğrunun var olduğuna } \\
\text { inanç }\end{array}$} & Kadın & 248 & 3,13 & 0,655 & \multirow{2}{*}{327} & \multirow{2}{*}{$-1,557$} & \multirow{2}{*}{, 120} \\
\hline & Erkek & 81 & 3,26 & 0,712 & & & \\
\hline \multirow{2}{*}{$\begin{array}{l}\text { Araştırma-sorgulamaya dayalı } \\
\text { fen öğretimi öz yeterlilik inanc1 }\end{array}$} & Kadın & 248 & 4,15 & 0,409 & \multirow{2}{*}{327} & \multirow{2}{*}{1,646} & \multirow{2}{*}{, 101} \\
\hline & Erkek & 81 & 4,06 & 0,408 & & & \\
\hline \multirow{2}{*}{ Bilimsel tutum } & Kadın & 248 & 3,45 & 12,27 & \multirow{2}{*}{327} & \multirow{2}{*}{$-1,366$} & \multirow{2}{*}{,173 } \\
\hline & Erkek & 81 & 3,40 & 14,75 & & & \\
\hline
\end{tabular}

Tablo 5'te de görüldüğü gibi, kadın $(M=2,59 ; S=0,894)$ ve erkek $(M=2,96 ; S=0,897)$ öğretmen adayları arasında, öğrenmenin yeteneğe bağlı olduğuna inanç değişkeni açısından

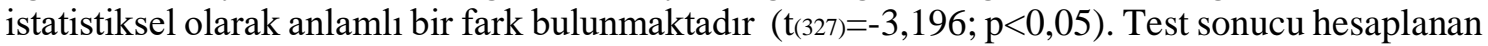
etki büyüklüğü $(\mathrm{d}=0,41)$ bu farkın orta düzeyde olduğunu göstermektedir (Gravetter ve Wallnau, 2007). Bu bulgu, erkek öğretmen adaylarının, öğrenmenin yeteneğe bağlı olduğuna dair inançlarının kadın öğretmen adaylarına göre daha yüksek olduğunu söylemektedir. Araştırmanın diğer değişkenleri açısından kadın ve erkek öğretmen adayları arasında istatistiksel olarak anlamlı farklar gözlenmemiştir $(\mathrm{p}>0,05)$.

\section{Öğretmen adaylarının epistemolojik inançların alt faktörleri ile araştırma-sorgulamaya dayalı fen öğretimi öz yeterlilik inançları ve bilimsel tutumları arasındaki ilişkiler ile ilgili bulgular}

Araştırmaya katılan fen bilgisi öğretmen adaylarının öğrenmenin çabaya bağlı olduğuna dair inançları, öğrenmenin yeteneğe bağlı olduğuna dair inançları ve tek bir doğrunun olduğuna dair inançları, araştırma-sorgulamaya dayalı fen öğretimi öz yeterlilik inançları ve bilimsel tutumları arasındaki olası ilişkileri incelemek amacıyla Pearson korelasyon analizi yapılmıştır (Tablo 6).

Tablo 6.

Araştırmanın Değişkenlerine Göre Korelasyon Katsayıları

\begin{tabular}{lllll}
\hline & $\begin{array}{l}\text { Öğr. çabaya } \\
\text { bağlı old. } \\
\text { inanç }\end{array}$ & $\begin{array}{l}\text { Öğg. yeteneğe } \\
\text { bağlı old. } \\
\text { inanç }\end{array}$ & $\begin{array}{l}\text { Tek bir } \\
\text { doğru old. } \\
\text { inanç }\end{array}$ & $\begin{array}{l}\text { Arş. dayalı } \\
\text { fen öğr. } \\
\text { inanç }\end{array}$ \\
\hline Öğr. yeteneğe bağlı old. inanç & $0,132^{*}$ & - & - & - \\
Tek bir doğru old. inanç & 0,022 & $0,624 * *$ & - & - \\
Arş. dayalı fen öğr. inanç & $-0,573^{* *}$ & $-0,048$ & 0,009 & - \\
Bilimsel tutum & $-0,369^{* *}$ & $-0,033$ & $-0,009$ & $0,287 * *$ \\
\hline
\end{tabular}

*Korelasyon 0.05 düzeyinde anlamlıdır.

** Korelasyon 0.01 düzeyinde anlamlıdır.

Araştırmaya katılan fen bilgisi öğretmen adaylarının, öğrenmenin yeteneğe bağl1 olduğuna inançları ile öğrenmenin çabaya bağlı olduğu inançları $(r=0,132, p<0,05)$, tek bir doğrunun varlığına inançları ile öğrenmenin yeteneğe bağlı olduğu inançları $(r=0,624, p<0,01)$ ve bilimsel tutumları ile araştırma-sorgulamaya dayalı fen öğretimi öz yeterlilik inançları $(r=0,287$, $\mathrm{p}<0,01)$ arasında pozitif yönde ve anlamlı düzeyde bir ilişki olduğu görülmektedir. Diğer yandan, öğretmen adaylarının, araştırma-sorgulamaya dayalı fen öğretimi öz yeterlilik inançları ile öğrenmenin çabaya bağlı olduğu inançları $(\mathrm{r}=-0,573, \mathrm{p}<0,01)$, bilimsel tutumları ile öğrenmenin çabaya bağlı olduğu inançları $(\mathrm{r}=-0,369, \mathrm{p}<0,01)$ ile tek bir doğrunun varlığına inançları $(\mathrm{r}=-$ $0,200, p<0,05)$ arasında negatif yönde ve anlamlı düzeyde bir ilişki olduğu görülmüştür. 
Fen bilgisi öğretmen adaylarının epistemolojik inançların alt faktörlerinin araştırmasorgulamaya dayalı fen öğretimi öz yeterlilik inançlarını yordamasına ilişkin bulgular

Araştırmaya katılan fen bilgisi öğretmen adaylarının, öğrenmenin çabaya bağlı olduğuna dair inançlarının, öğrenmenin yeteneğe bağlı olduğuna dair inançlarının ve tek bir doğrunun olduğuna dair inançlarının, araştırma-sorgulamaya dayalı fen öğretimi öz yeterlilik inançlarını yordama gücünü hesaplamak amacıyla çoklu regresyon analizi yapılmıştır. Regresyon analizinde, yordayıcı değişkenler arasında yüksek derecede ilişki bulunmaması gerekmektedir. İlgili değişkenler arasındaki korelasyon değerleri Tablo 6'da verilmiştir. Bu Tablo incelendiğinde, modele giren değişkenlerin korelasyon değerlerinde çoklu bağlantı olmadığı, yani her bir korelasyon değerinin 0,80'den küçük olduğu görülmüştür (Büyüköztürk, 2011). Yordayıc1 değişkenler arasında çoklu korelasyon olup olmadığını belirlemek amacıyla ayrıca, varyans büyütme faktörlerine (VIF) ve tolerans değerlerine bakılmıştır. Değerler Tablo 7'de sunulmuştur.

Tablo 7.

Yordayıc1 Değişkenlerin Yordamaya İlişkin Çoklu Bağlantı Değerleri

\begin{tabular}{lll}
\hline Değişken & VIF değerleri & Tolerans değerleri \\
\hline Öğrenmenin çabaya bağlı olduğuna inanç & 1,024 & 0,977 \\
Öğrenmenin yeteneğe bağlı olduğuna inanç & 1,677 & 0,596 \\
Tek bir doğrunun olduğuna inançları & 1,648 & 0,607 \\
\hline
\end{tabular}

Tablo 7 incelendiğinde VIF değerlerinin 10'dan düşük olduğu ve tolerans değerlerinin de 0,20 'den yüksek olduğu görülmektedir. Elde edilen bu korelasyon değerleri, değişkenler arasında çoklu bağlantı olmadığını göstermektedir (Büyüköztürk, 2011). Araştırma-sorgulamaya dayalı fen öğretimi öz yeterlilik inançları regresyon analizi sonuçları Tablo 8'de sunulmuştur.

Tablo 8.

Araştırma-Sorgulamaya Dayalı Fen Öğretimi Öz Yeterlilik İnançları Regresyon Analizi Sonuçları

\begin{tabular}{|c|c|c|c|c|c|c|c|}
\hline & & Stand & & & & & \\
\hline Değişken & B & Hata & $\beta$ & $\mathrm{t}$ & $\mathrm{p}$ & İkili r & K1smi r \\
\hline Sabit & 5,072 & ,119 & - & 42,708 & ,000 & - & - \\
\hline $\begin{array}{l}\text { Öğrenmenin çabaya } \\
\text { bağlı old. dair inanç }\end{array}$ &,- 507 & ,041 &,- 576 & $-12,501$ & ,000 &,- 573 &,- 570 \\
\hline $\begin{array}{l}\text { Öğrenmenin } \\
\text { yeteneğe bağl1 old. } \\
\text { dair inanç }\end{array}$ & ,010 & ,027 & ,023 & ,382 & ,703 &,- 048 & ,021 \\
\hline $\begin{array}{l}\text { Tek bir doğrunun } \\
\text { old. dair inanç }\end{array}$ & ,005 & ,036 & ,008 & ,145 & ,885 & ,009 & ,008 \\
\hline $\begin{array}{l}\mathrm{R}=0,573 \\
\mathrm{~F}_{(3-324)}=52,878\end{array}$ & \multicolumn{7}{|c|}{$\begin{array}{l}\mathrm{R}_{2}=0,329 \\
\mathrm{p}=0,000\end{array}$} \\
\hline
\end{tabular}

Fen bilgisi öğretmen adaylarının araştırma-sorgulamaya dayalı fen öğretimi öz yeterlilik inançları üzerinde etkisi olduğu düşünülen öğrenmenin çabaya bağlı olduğuna dair inanç, öğrenmenin yeteneğe bağlı olduğuna dair inanç ve tek bir doğrunun olduğuna dair inanç değişkenlerinin araştırma-sorgulamaya dayalı fen öğretimi öz yeterlilik inancını ne şekilde yordadığını ortaya koymak için yapılan çoklu regresyon analizi sonucunda, bu üç yordayıcı değişkenin birlikte araştırma-sorgulamaya dayalı fen öğretimi öz yeterlilik inancı ile anlamlı bir ilişki $\left(\mathrm{R}=0,573, \mathrm{R}_{2}=0,329\right)$ sergiledikleri görülmüştür $\left(\mathrm{F}_{(3-324)}=52,878, \mathrm{p}<0,01\right)$. Bu üç değişken, birlikte, araştırma-sorgulamaya dayalı fen öğretimi öz yeterlilik inancındaki değişimin \%33'ünü açıklamaktadırlar. Standartlaştırılmış regresyon katsayılarına göre bu değişkenlerin yordanan üzerindeki önem sırası, öğrenmenin çabaya bağlı olduğuna dair inanç $(\beta=-0,576)$, öğrenmenin yeteneğe bağl1 olduğuna dair inanç $(\beta=0,023)$ ve tek bir doğrunun olduğuna dair inanç $(\beta=0,008)$ şeklindedir. Regresyon katsayılarının anlamlılık testleri göz önüne alındığında ise, yordayıcı 
değiş̧kenlerden sadece öğrenmenin çabaya bağlı olduğuna dair inanç $(p<0,01)$ değişkeninin araştırma-sorgulamaya dayalı fen öğretimi öz yeterlilik inancı üzerinde anlamlı bir yordayıc1 olduğu görülmektedir.

Fen bilgisi öğretmen adaylarının epistemolojik inançlarının alt faktörlerinin bilimsel tutumlarını yordamasına ilişkin bulgular

Araştırmaya katılan fen bilgisi öğretmen adaylarının, öğrenmenin çabaya bağlı olduğuna dair inançlarının, öğrenmenin yeteneğe bağlı olduğuna dair inançlarının ve tek bir doğrunun olduğuna dair inançlarının, bilimsel tutumlarını yordama gücünü hesaplamak amacıyla çoklu regresyon analizi yapılmıştır. Yordayıcı değişkenler arasındaki korelasyon değerleri Tablo 6'da verilmiştir. Daha önce de belirtildiği gibi, modele giren değişkenlerin korelasyon değerlerinde çoklu bağlantı olmadığı görülmektedir. Değişkenlere ait, varyans büyütme faktörleri (VIF) ve tolerans değerleri de Tablo 9'da sunulmuştur.

Tablo 9.

Yordayıı Değişkenlerin Yordamaya İlişkin Çoklu Bağlantı Değerleri

\begin{tabular}{lll}
\hline Değişken & VIF değerleri & Tolerans değerleri \\
\hline Öğrenmenin çabaya bağlı olduğuna inanç & 1,024 & 0,977 \\
Öğrenmenin yeteneğe bağlı olduğuna inanç & 1,675 & 0,597 \\
Tek bir doğrunun olduğuna inançları & 1,647 & 0,607 \\
\hline
\end{tabular}

Tablo 9'da VIF değerlerinin 10'dan düşük olduğu ve tolerans değerlerinin de 0,20 'den yüksek olduğu görülmektedir. Bu değerler, değişkenler arasında çoklu bağlantı olmadığını göstermektedir (Büyüköztürk, 2011). Tablo 10'da bilimsel tutuma yönelik regresyon analizi sonuçları verilmiştir.

Tablo 10.

Bilimsel Tutum Regresyon Analizi Sonuçları

\begin{tabular}{lccccccc}
\hline Değişken & $\mathrm{B}$ & $\begin{array}{c}\text { Standart } \\
\text { Hata }\end{array}$ & $\beta$ & $\mathrm{t}$ & $\mathrm{p}$ & İkili r & Kısmi r \\
\hline $\begin{array}{l}\text { Sabit } \\
\text { Öğrenmenin }\end{array}$ & 3,931 &, 105 & - & 37,452 &, 000 & - & - \\
$\begin{array}{l}\text { çabaya bağlı old. } \\
\text { dair inanç }\end{array}$ &,- 256 &, 036 &,- 372 & $-7,132$ &, 000 &,- 369 &,- 368 \\
$\begin{array}{l}\text { Öğrenmenin } \\
\text { yeteneğe bağlı old. } \\
\text { dair inanç }\end{array}$ &, 009 &, 024 &, 026 &, 391 &, 696 &,- 033 &, 022 \\
$\begin{array}{l}\text { Tek bir doğrunun } \\
\text { old. dair inanç }\end{array}$ &,- 008 &, 032 &,- 016 &,- 248 &, 804 &,- 009 &,- 014 \\
\hline $\begin{array}{l}\mathrm{R}=0,369 \\
\mathrm{~F}(3-325)=17,126\end{array}$ & $\begin{array}{l}\mathrm{R} 2=0,137 \\
\mathrm{p}=0,000\end{array}$ & & & & & & \\
\hline
\end{tabular}

Tablo 10 incelendiğinde, fen bilgisi öğretmen adaylarının bilimsel tutumları üzerinde etkisi olduğu düşünülen öğrenmenin çabaya bağlı olduğuna dair inanç, öğrenmenin yeteneğe bağlı olduğuna dair inanç ve tek bir doğrunun olduğuna dair inanç değişkenlerinin bilimsel tutumu ne şekilde yordadığını ortaya koymak için yapılan çoklu regresyon analizi sonucunda, bu üç yordayıc1 değişkenin birlikte bilimsel tutum ile anlamlı bir ilişki $(\mathrm{R}=0,369, \mathrm{R} 2=0,137)$ sergiledikleri görülmüştür $\left(\mathrm{F}_{(3-325)}=17,126, \mathrm{p}<0,01\right)$. Bu üç değişken, birlikte, bilimsel tutumdaki değişimin \%14'ünü açıklamaktadırlar. Standartlaştırılmış regresyon katsayılarına göre bu değişkenlerin yordanan üzerindeki önem sırası, öğrenmenin çabaya bağlı olduğuna dair inanç $(\beta=-0,372)$, öğrenmenin yeteneğe bağlı olduğuna dair inanç $(\beta=0,026)$ ve tek bir doğrunun olduğuna dair inanç $(\beta=-0,016)$ şeklindedir. Regresyon katsayılarının anlamlılık testleri göz 
önüne alındığında ise, yordayıcı değişkenlerden sadece öğrenmenin çabaya bağlı olduğuna dair inanç $(\mathrm{p}<0,01)$ değişkeninin bilimsel tutum üzerinde anlamlı bir yordayıcı olduğu görülmektedir.

\section{Tartışma ve Sonuç}

$\mathrm{Bu}$ araştırmada, fen bilgisi öğretmen adaylarının epistemolojik inançları, öğrenmenin çabaya bağlı olduğuna dair inanç, öğrenmenin yeteneğe bağlı olduğuna dair inanç ve tek bir doğrunun varlığına dair inanç alt boyutları göz önünde bulundurularak incelenmiştir. Araştırmaya katılan fen bilgisi öğretmen adaylarının öğrenmenin çabaya bağlı olduğuna dair inançlarına ait ortalama puanlarının $(\mathrm{M}=1,93)$ oldukça düşük olduğu görülmüştür. Puan ortalaması düştükçe daha sofistike bir inanç sergilendiğinden, fen bilgisi öğretmen adaylarının, öğrenmenin gerçekleşebilmesi için çaba sarf etmek gerektiğine inandıkları söylenebilir. Bu anlamda, fen bilgisi öğretmen adaylarının öğrenme sürecinde çaba, olumlu bir durum olarak düşünülmektedir. Öğretmen adaylarının öğrenmenin yeteneğe bağlı olduğuna dair inanca ait puan ortalamaları $(\mathrm{M}=2,68)$ ile tek bir doğrunun var olduğuna dair inanca ait ortalama puanları $(\mathrm{M}=3,17)$ ise orta değere yakındır. Schommer'e (1990) göre ortada yer alan bireyler (2,50 ile 3,50 ortalama) güçlü bir inanç sergilemedikleri yönünde yorumlanmaktadırlar. Araştırmada ayrıca, kadın ve erkek öğretmen adayları arasında epistemolojik inanç alt boyutları bakımından farklar bulunmuştur. $\mathrm{Bu}$ farklar kadın öğretmen adaylarının ortalamalarının tüm alt boyutlarda erkeklere göre daha düşük olduğunu göstermektedir. Bu durum, kadın öğretmen adaylarının erkek öğretmen adaylarına göre daha sofistike epistemolojik inançlara sahip olduğunu söyleyebilir. Ancak, bu farklılıkların istatistiksel olarak anlamlı olup olmadığını araştırmak için yapılan t-testi analiz sonucunda, farkın yalnızca öğrenmenin yeteneğe bağlı olduğuna dair inanç boyutunda istatistiksel olarak anlamlı olduğu görülmüştür. Bu bulgu, kadın öğretmen adaylarının, öğrenmenin yeteneğe bağlı olduğuna dair inançlarının erkek öğretmen adaylarına göre daha yüksek olduğunu göstermektedir. İlgili alanyazında epistemolojik inançların cinsiyete göre farklılığını araştıran çalışmalar mevcuttur. Örneğin, Deryakulu ve Büyüköztürk (2005), üniversite öğrencileri ile gerçekleştirdikleri çalışmalarında, kadın öğrencilerin erkek öğrencilere göre daha gelişmiş epistemolojik inançlara sahip olduklarını bulmuşlardır. Diğer yandan, Izgar ve Dilmaç (2008) araştırmalarında, yönetici adayı öğretmenlerin epistemolojik inanç alt boyutları ile cinsiyet arasındaki ilişkiyi incelemiş, herhangi bir farklılaşma olmadığını gözlemlemişlerdir. Benzer şekilde, Terzi (2005) tarafından gerçekleştirilen bir başka araştırmada da üniversite öğrencilerinin cinsiyetleri ile epistemolojik inançları arasında anlamlı bir ilişki bulunamamıştır.

Mevcut araştırmada fen bilgisi öğretmen adaylarının araştırma-sorgulamaya dayalı fen öğretimi öz yeterlilik inançlarının genel olarak ve ölçme aracının tüm alt boyutlarında (firsat, rehberlik, kanıt ve açıklama) olumlu düzeyde olduğu gözlenmiştir. Bir başka deyişle, fen bilgisi öğretmen adayları kendilerini ve öğrencilerini bilimsel sorularla meşgul etme, soruları cevaplamadan kanıtlar sunma ve kanıtları kullanarak açıklamalar yapma ve açılamalarını savunma konularında yeterli görmektedirler. Ancak, diğer yandan, öğretmen adaylarının bilimsel tutumları, yani bilimsel olayların yapısı, doğası, amacı, bilimsel düşünme, bilimsel davranış ve bilimsel yöntem gibi konulardaki tavırları kararsız düzeyde kalmıştır. Bu araştırmada ayrıca, öğretmen adaylarının araştırma-sorgulamaya dayalı fen öğretimi öz yeterlilik inançlarının ve bilimsel tutumlarının cinsiyete göre değişip değişmediği de incelenmiş ve kadın ve erkekler arasında bu iki değişken bakımından farlılık gözlenmemiştir. Bu bulgu ile benzer şekilde, Özdemir ve Sak (2013) tarafından gerçekleştirilen araştırmada da bilimsel tutum ile cinsiyet arasında anlamlı bir ilişki bulunmamıştır. İnaltekin ve Akçay (2011) tarafından yapılan çalışmada fen bilimleri öğretmenlerinin sorgulama tabanlı fen öğretimi öz-yeterlilikleri ile cinsiyet değişkeni arasında anlamlı bir fark olmadığı görülmüştür. Aslan ve Uluçınar Sağır (2008) ve Türkmen'in (2002) yaptığı çalışmalarda da cinsiyet ile bilimsel tutum arasında anlamlı farklılık olmadığ 1 bulunmuştur.

$\mathrm{Bu}$ araştırmada ayrıca, çoklu regresyon analizleri öncesi, araştırmanın değişkenleri arasındaki olası ilişkiler incelenmiştir. Fen bilgisi öğretmen adaylarının öğrenmenin yeteneğe bağlı olduğuna dair inançları ile öğrenmenin çabaya bağlı olduğu ve tek bir doğrunun varlığına dair inançları arasında pozitif yönde ve anlamlı düzeyde ilişkiler gözlenmiştir. Ayrıca, fen bilgisi 
öğretmen adaylarının bilimsel tutumları ile araştırma-sorgulamaya dayalı fen öğretimi öz yeterlilik inançları arasında da pozitif yönde ve anlamlı düzeyde bir ilişki olduğu görülmüştür. Öğrenmenin gerçekleşebilmesinin yetenekle ilgili olduğuna dair yüksek düzeyde inanç gösterenlerin, öğrenmenin çaba gerektirdiğine dair ve bilginin mutlak olduğuna dair de yüksek düzeyde inanç gösterme eğiliminde oldukları görülmüştür. Ayrıca, bilimsel tutumları yüksek olan öğretmen adaylarının araştırma-sorgulamaya dayalı fen öğretimi öz yeterlilik inançlarının da yüksek olma eğiliminde olduğu görülmüştür. Diğer yandan, öğretmen adaylarının, araştırmasorgulamaya dayalı fen öğretimi öz yeterlilik inançları ile öğrenmenin çabaya bağlı olduğu inançları, bilimsel tutumları ile öğrenmenin çabaya bağlı olduğu inançları arasında negatif yönde ve anlamlı düzeyde ilişkiler olduğu görülmüştür. Öğrenmenin çaba gerektirdiğine dair inancı yüksek olan öğretmen adaylarının araştırma-sorgulamaya dayalı fen öğretimi öz yeterlilik inancı ve bilimsel tutumları düşük olma eğiliminde olmuştur. Alanyazında bu ilişkileri inceleyen pek fazla araştırmaya rastlanmamakla birlikte, Izgar ve Dilmaç'ın (2008) yaptıkları araştırmada yönetici adayı öğretmenlerin epistemolojik inançları ile öz yeterlilik arasındaki ilişki incelenmiş; epistemolojik inançların üç alt boyutu olan, öğrenmenin çabaya bağlı olduğu inanc1, yeteneğe bağlı olduğu inancı ve tek bir doğrunun olduğu inançları arasında pozitif yönlü ilişkiler bulunmuştur.

Araştırmada son olarak, fen bilgisi öğretmen adaylarının epistemolojik inançlarının araştırma-sorgulamaya dayalı fen öğretimi öz yeterlilik inançlarını ve bilimsel tutumlarını tahmin etme düzeyleri incelenmiştir. Araştırma-sorgulamaya dayalı fen öğretimi öz yeterlilik inancı üzerinde etkisi olduğu düşünülen öğrenmenin çabaya bağlı olduğuna dair inanç, öğrenmenin yeteneğe bağlı olduğuna dair inanç ve tek bir doğrunun olduğuna dair inanç değişkenlerinden öğrenmenin çabaya bağlı olduğuna dair inancın, araştırma-sorgulamaya dayalı fen öğretimi öz yeterlilik inancındaki değişimin \%33'ünü açıkladığ 1 görülmüştür. Araştırma ve sorgulamaya dayalı fen sınıflarında öğrencilerin bilimsel sorularla meşgul olması, bu soruları yanıtlarken kanıtlar araması, bu kanıtlardan elde ettiği açıklamaları formüle etmesi ve açıklamaları bilimsel bilgiye bağlaması gibi çaba gerektiren öğretim stratejileri ile meşgul olması gerektiği düşünüldüğünde (NRC, 2000; Smolleck, Zembal-Saul ve Yoder, 2006), öğrenmenin çabaya bağl1 olduğuna dair inancın araştırma ve sorgulamaya dayalı fen öğretimi öz-yeterlilik inancı üzerindeki değişimi bu düzeyde açıklıyor olması şaşırtıcı görünmemektedir. Öğrenmenin çabaya bağlı olduğuna dair inanç, bu araştırmada ayrıca, bilimsel tutumdaki değişimin \%14'ünü açıklamıştır. Bilimsel tutuma sahip bireylerin, araştıran, eleştiren, peşin yargıların ve dogmatik inançların etkisinde kalmayan ve karşılaştıkları sorunlara çözüm yolları arayan ve bu yolları uygulayan bireyler oldukları söylenmektedir (Demirbaş ve Yağbasan, 2006). Bu bulgularla birlikte, epistemolojik inancın gerek araştırma-sorgulamaya dayalı fen öğretimine yönelik öz yeterlilik inanc1 gerekse bilimsel tutumu etkileyen önemli bir yordayıcı değişken olduğu düşünülmektedir.

Araştırma-sorgulamaya dayalı fen öğretimi öz yeterlilik inancı ve bilimsel tutum üzerindeki yordayıcı etkisi göz önünde bulundurulduğunda, öğretmen adaylarının epistemolojik inançlarını geliştirebilecek eğitim-öğretim faaliyetlerinin öğretim programlarına dâhil edilmesi önerilebilir. Öğretmen adaylarından ders planlarını ve sınıf ortamlarını düzenlerken bu değişkenlerin geliştirilmesini de hedefleyecek planlar yapmaları istenebilir. Bu araştırmada fen bilgisi öğretmen adaylarının epistemolojik inançları, araştırma-sorgulamaya dayalı fen öğretimi öz yeterlilik inançları, bilimsel tutumları ve akademik başarıları arasındaki ilişkiler incelenmiştir. Söz edilen değişkenler ile ilişkili olabilecek (örn., sosyo-kültürel yapı gibi) başka değişkenleri de içeren farklı araştırmaların yapılmasının ilgili alanyazına katkı sağlayacağı düşünülmektedir. Ayrıca, nicel araştırma deseninde gerçekleştirilen bu araştırma bulgularının nitel verilerle de desteklenerek daha detaylı incelenmesi önerilebilir.

\section{Kaynaklar}

Aslan, O. ve Uluçınar Sağır, Ş. (2008). Fen ve teknoloji öğretmen adaylarının bilimsel tutumlarının, öz yeterlik inanç düzeylerinin ve etki eden faktörlerin belirlenmesi, Proceedings of the 8th International Education Technology Conference, 868-873. 
Fen Bilgisi Öğretmen Adaylarının Epistemolojik İnançlarının Araştırma Sorgulamaya Dayalı Fen

Öğretimi ve Bilimsel Tutum Üzerine Etkilerinin Çoklu Regresyon ile Analizi

Avcı, M. (2019). Fen bilgisi ögrretmen adaylarının epistemolojik inançlarıyla sorgulamaya dayalı fen ögretimi inançları, bilimsel tutumları ve akademik başarıları arasındaki ilişsinin incelenmesi (Yayınlanmamış yüksek lisans tezi). Sinop Üniversitesi Fen Bilimleri Enstitüsü, Sinop.

Başaran, İ. E. (1978). Ĕgitim Psikolojisi. Ankara: Bilim Matbaası.

Brownlee, J., Purdie, N. ve Boulton-Lewis, G. (2001). Changing epistemological beliefs in preservice teacher education students. Teaching in Higher Education, 6(2), 247-268.

Büyüköztürk, Ş. (2011). Deneysel desenler: Öntest-sontest kontrol grubu, desen ve veri analizi. Ankara: Pegem Akademi.

Demir, Ö. ve Acar, M. (1992). Sosyal bilimler sözlüğü. İstanbul: Ağaç Yayıncılık.

Demirbaş, M. ve Yağbasan, R. (2006). Fen bilgisi öğretiminde bilimsel tutumları işlevsel önemi ve bilimsel tutum ölçeğinin Türkçeye uyarlanma çalışması. Uludă̆ Üniversitesi Ĕgitim Fakültesi Dergisi, 19(2), 271-299.

Deryakulu, D. ve Büyüköztürk, Ş. (2005). Epistemolojik inanç ölçeğinin faktör yapısının yeniden incelenmesi, cinsiyet ve öğrenim görülen program türüne göre epistemolojik inançların karşılaştırılması. Ĕgitim Araştırmaları, 18, 57-70.

Deryakulu, D. (2002). Denetim odağı ve epistemolojik inançların öğretim materyalini kavramayı denetleme türü ve düzeyi ile ilişkisi. Hacettepe Üniversitesi Ĕgitim Fakültesi Dergisi, 22, 55-61.

Deryakulu, D. (2006). Epistemolojik inançlar. Y. Kuzgun ve D. Deryakulu (Yay. haz.), Eğitimde Bireysel Farklılıklar, içinde (ss. 261-284). Ankara: Nobel Yayın Dağıtım.

Dewey, J. (1933). How we think. New York: D.C. Heath and Company.

Duschl, R. A., Schweingruber, H. A. ve Shouse, A. W. (2007). Taking science to school: Learning and teaching science in grades K-8. Washington, DC: National Academies Press.

Fraenkel, J. R. ve Wallen, N. E. (1996). How to design and evaluate research in education. New York: McGraw-Hill.

Gravetter, F. J. ve Wallnau, L. B. (2007). Statistics for the behavioral sciences (7th ed.). Thomson Wadsworth.

Izgar, H. ve Dilmaç, B. (2008). Yönetici adayı öğretmenlerin özyeterlik algıları ve epistemolojik inançların incelenmesi. Selçuk Üniversitesi Sosyal Bilimler Enstitüsü Dergisi, 20, 437446.

İnaltekin, T. ve Akçay, H. (2011). Araştırma tabanlı fen öğretimi ölçeğinin Türkçe uyarlaması: geçerlilik ve güvenirlik çalışması. Trakya Üniversitesi Eğitim Fakültesi Dergisi, l(2),158-185.

Karhan, İ. (2007). İlköğretim okullarında görev yapan ögretmenlerin epistemolojik inançlarının demografik özelliklerine ve bilgi teknolojilerini kullanma durumlarına göre incelenmesi (Yayımlanmamış doktora tezi). Yıldız Teknik Üniversitesi Sosyal Bilimler Enstitüsü, İstanbul.

Liaghatdar, M. J., Jafari, E., Abedi, M. R. ve Samiee, F. (2008). Reliability and validity of the Oxford happiness inventory among university students in Iran. The Spanish Journal of Psychology, 11(1), 310-313.

Matthews, M. R. (2017). Fen ögretimi bilim tarihinin ve felsefesinin katklsı. (M. Doğan, Çev.) İstanbul: Boğaziçi Üniversitesi Yayınevi.

Mıhladız, G. ve Duran, M. (2011). İlköğretim öğrencilerinin bilime yönelik tutumlarının demografik değişkenler açısından incelenmesi. Mehmet Akif Ersoy Üniversitesi Eğitim Fakültesi Dergisi, 1(20), 100-121.

Milli Eğitim Bakanlığı (MEB) (2018). Fen Bilimleri Dersi (İlkokul ve Ortaokul 3, 4, 5, 6, 7 ve 8. Sinıflar) Öğretim Programı. Ankara: Talim Terbiye Kurulu Başkanlığı.

Moore, R. W. ve Foy, R. L. H. (1997). The scientific attitude inventory: A revision (SAI II). Journal of Research in Science Teaching: The Official Journal of the National Association for Research in Science Teaching, 34(4), 327-336.

National Research Council (NRC) (1996). National science education standarts. Washington, DC: The National Academies Press. 
National Research Council (NRC) (2000). Inquiry and the national science education standards: A guide for teaching and learning. Washington, DC: National Academy Press.

Özdemir, N. N. ve Sak, U. (2013). Bilimsel yaratıcılıkta cinsiyet farklılıklarının bileşensel analizi. Türk Üstün Zeka ve Eğitim Dergisi, 3(2), 53-65.

Pajares, F. (1992). Teachers' beliefs and educational research: Cleaning up a messy construct. Review of Educational Research, 62, 307-332.

Schommer, M. A. (1990). Effects of beliefs about the nature of knowledge on comprehension. Journal of Educational Psychology, 82(3), 498-504.

Smolleck, L. D., Zembal-Saul, C. ve Yoder, E. P. (2006). The development and validation of an instrument to measure preservice teachers' self-efficacy in regard to the teaching of science as inquiry. Journal of Science Teacher Education, 17, 137-163.

Terzi, A. R. (2005). Üniversite öğrencilerinin bilimsel epistemolojik inançları üzerine bir araştırma. Afyon Kocatepe Üniversitesi Sosyal Bilimler Dergisi, 7(2), 298-311.

Türkmen, L. (2002). Sınıf öğretmenliği 1. sınıf öğrencilerinin fen bilimleri ve fen bilgisi öğretimine yönelik tutumları. Hacettepe Üniversitesi Ĕgitim Fakültesi Dergisi, 23, 218228.

\section{Extended Abstract}

\section{Introduction}

The aim of this study is to investigate the relationships among pre-service science teachers' epistemological beliefs, science teaching beliefs and scientific attitudes. Epistemological beliefs are related to the nature, limits, accuracy, reliability and validity of knowledge (Demir \& Acar, 1992). Epistemological beliefs of individuals are described as sophisticated and naive (Brownlee et al., 2001). Individuals showing naïve epistemological beliefs believe that knowledge is absolute and therefore can be transmitted from an expert. They think that knowledge has a simple structure, consisting of a single piece, and is absolutely right or wrong; and the ability to learn is an innate characteristic that is genetically derived (Deryakulu, 2002). Individuals with sophisticated epistemological beliefs, on the other hand, believe that knowledge is relative, tentative and reconfigurable (Brownlee et al., 2001). They see knowledge as a complex structure composed of many interconnected parts, and think that the ability to learn can develop, learning can occur over time depending on effort and knowledge can be built on the basis of experimental evidence or through the mind of individuals.

Scientific attitude, on the other hand, is described as the willingness to understand and know, to collect data and make research (Demirbaş \& Yağbasan, 2006). Individuals with scientific attitudes have critical thinking abilities and are away from the influence of prejudices and dogmatic belief systems. Scientific attitudes are not only related to the achievements of individuals, but also to the continuation of personal development (Başaran, 1978). According to Liaghatdar et al. (2008), while students with positive scientific attitudes are progressing towards their achievements and life, their interest in science and science-related issues is also increasing. Students who have positive attitudes towards science develop positive attitudes towards their education programs, courses, teachers and schools (Mihladiz \& Duran, 2011). In this context, science teaching based on research and inquiry becomes important in the development of positive scientific attitudes among students. Inquiry; including student activities like making observations, planning and conducting research, reviewing the knowledge through experimental evidence, analyzing data, interpreting results and communicating it with others, is similar to scientific activities (NRC, 1996).

In recent years, along with the constructivist learning approach, inquiry-based learning has gained importance in science education. The recent national science curricula (MoNE, 2018) in Turkey, assigned inquiry-based teaching as the main teaching strategy in science education. Students are, therefore, expected to investigate, question and understand that knowledge can change over time and these changes occur as a result of the values, social structures and beliefs of the culture in which they live. At this point, it becomes a necessity to investigate the level of 
science teaching beliefs, epistemological beliefs and scientific attitudes of pre-service teachers, who will hold the responsibility to bring these knowledge and skills to their students. Herein, the aim of this research was determined as to investigate pre-service science teachers' epistemological beliefs, inquiry-based science teaching self-efficacy beliefs and scientific attitudes, and the relationships among these variables.

\section{Method}

The study is designed as a survey research and the sample consisted of 329 pre-service science teachers from 6 different state universities. Data were collected using Epistemological Beliefs Questionnaire, Teaching Science as Inquiry Instrument and Scientific Attitude Scale. Data were analyzed through descriptive and inferential statistical analyzes. For each variable of the study, descriptive analyzes including minimum, maximum, mean and standard deviation values were performed, and independent samples t-test was conducted to examine whether the mean values change significantly with respect to gender. The relationships among the variables of the study were tested by Pearson moment-product correlation, while the power of the belief that learning depends on effort, the belief that learning depends on ability and the belief that there is a single truth, to predict teaching science as inquiry, scientific attitude and academic achievement were tested by multiple regression analyses.

\section{Result and Discussion}

According to the results of this study, pre-service science teachers believed in the necessity of making effort for learning to take place. They did not show strong beliefs about the necessity of innate ability for learning to take place and the existence of the single truth. In the study, female pre-service science teachers were found to hold stronger beliefs that learning depends on innate ability when compared to males. Pre-service science teachers' inquiry-based science teaching self-efficacy beliefs were positive in all sub-dimensions of the instrument (i.e., opportunity, guidance, evidence and explanation), meaning that they believe in the need to engage themselves and their students with scientific questions, provide evidence before answering questions and defend their explanations. In the study, positive and significant relationships were found between inquiry-based science teaching self-efficacy and scientific attitudes. In other words, as pre-service science teachers' scientific attitudes improved, self-efficacy beliefs about inquiry-based science teaching increased.

In the study, multiple regression analyses were performed to determine the contributions of epistemological beliefs on pre-service science teachers' inquiry-based science teaching selfefficacy and scientific attitudes. Findings showed that the belief that learning depends on effort explained $33 \%$ of the variance in inquiry-based science teaching self-efficacy, while it explained $14 \%$ of the variance in scientific attitude. Considering the predictive power of inquiry-based science teaching self-efficacy and scientific attitude, it may be suggested to include educational activities in their programs of study that can improve pre-service science teachers' epistemological beliefs. In the study, the relationships among pre-service science teachers' epistemological beliefs, inquiry-based science teaching self-efficacy beliefs and scientific attitudes were examined. It is thought that conducting different studies including other variables that may be related to these variables (e.g. socio-cultural structure) will contribute to the relevant literature. In addition, it can be suggested that the findings of the research conducted in the quantitative research design should be supported with qualitative data and examined in more detail. 